\title{
ЕКОЛОГІЧНІ ТА ЕКОНОМІЧНІ КОМПЕТЕНТНОСТІ ЯК ПІДГРУНТЯ ДЛЯ ФОРМУВАННЯ ЕКОЛОГО-ЕКОНОМІЧНОГО МИСЛЕННЯ ЗДОБУВАЧІВ ВИЩОЇ ОСВІТИ
}

\begin{abstract}
Засобом і метою екологізування процесу підготовки фахівців для сталого розвитку є набуття ними системних екологоекономічних компетентностей та формування еколого-економічного мислення, яке грунтується на усвідомленні законів функціонування природних і соціальних систем та вмінні творчо застосовувати їх у професійній та повсякденній діяльності. Еколого-економічне мислення розглянуто як один із видів професійного мислення, що визначає здатність особи успішно здійснювати професійну та подальшу навчальну діяльність і є результатом навчання за відповідною освітньо-професійною (освітньо-науковою) програмою. Еколого-економічне мислення фахівців для сталого розвитку формується шляхом творчого застосування сучасних досягнень дидактики відповідно до специфіки підготовки фахівців різних професійних спрямувань, а також з урахуванням інтелектуальних відмінностей студентів окремих спеціальностей та їх вродженої схильності до переважного набуття певних компетентностей - природничих (екологічних), інженерно-технічних, економічних, соціально-гуманітарних, мистецьких тощо. Основними напрямами формування еколого-економічного мислення здобувачів вищої освіти $\epsilon$ поглиблення екологічної підготовки фахівців економічних спеціальностей, поглиблення економічної підготовки фахівців природничого (екологічного) спрямування та поглиблення екологічної та економічної підготовки фахівців усіх інших спрямувань.
\end{abstract}

Ключові слова: освіта в інтересах сталого розвитку; екологічна компетентність; економічна компетентність; екологоекономічна компетентність; еколого-економічне мислення

Вступ. Глобальні цілі сталого розвитку, прийняті у вересні 2015 р. на Саміті зі сталого розвитку в НьюЙорку (Agenda, 2015), у складі першочергових завдань передбачають: викорінення надзвичайної бідності, сталий розвиток сільського господарства, забезпечення здорового способу життя, загальну і справедливу якісну освіту, сприяння неухильному, всеохопному та сталому економічному зростанню, збереження i відновлення екосистем суходолу, раціональне використання лісів, зупинення процесу втрати біорізноманіття. Адаптація на національному рівні глобальної Програми 17 Цілей Сталого Розвитку, яку світ має досягнути до 2030 р., потребує розроблення довгострокової програми сталого розвитку і для України.

Реалізація завдань цієї програми передбачає формування особливого освітнього напряму - освіти в інтереcax сталого розвитку (ОСР), включення принципів сталого розвитку в усі освітні програми, які мають забезпечити постійне і неперервне навчання та виховання всіх членів суспільства як тих, хто навчає, так і тих, хто навчається.

Головним чинником забезпечення досягнення цілей OCР, як зазначає акад. Ю. Ю. Туниця (Tunytsia, 2010), повинна стати докорінна зміна традиційного меркантильно-економічного мислення (i способу господарювання 3 його руйнівними екологічними наслідками) на принципово нове еколого-економічне мислення та новий спосіб господарювання ("зелену" економіку) на засадах сталого розвитку.

Нове еколого-економічне мислення може формуватися насамперед через постійний розвиток якісної екологічної інформованості, виховання високої соціальної та моральної відповідальності щодо природного довкілля, пропагування узгодженого 3 принципами сталого розвитку способу життєдіяльності, тобто через загальне екологізування суспільної свідомості, важливою складовою якого $є$ екологізування освітньої діяльності.

Екологізування освітньої діяльності повинне забезпечити усвідомлене розуміння викладачами і студентами органічної єдності та взаємозалежності людини і природи. Глобальною кінцевою метою екологізування освітньої діяльності має стати "трансформація суспільної свідомості та економічного устрою шляхом інтеграції екологічного імперативу в різні галузі знань, у побудову нових моделей виробництва й споживання, формування нової системи господарювання" (Ekolohizatsiia, 2009).

Мета дослідження - обгрунтування теоретичних засад формування професійного еколого-економічного мислення здобувачів вищої освіти на основі екологічних та економічних компетентностей.

Аналіз останніх досліджень і публікацій. Методологічною основою концепції ОСР є Белградська хартія

\section{Інформація про авторів:}

Динька Павло Кузьмич, канд. екон. наук, доцент, директор HНI EEM. Email: dynka@nltu.edu.ua

Цитування за ДСту: Динька П. К. Екологічні та економічні компетентності як підґрунтя для формування еколого-економічного мислення здобувачів вищої освіти. Науковий вісник НЛтУ України. 2019, т. 29, № 10. С. 78-81.

Citation APA: Dynka, P. K. (2019). Enviromenral and economic competences as a prerequisite for evironmental and economic thinking development by students of higher education institutions. Scientific Bulletin of UNFU, 29(10), 78-81.

https://doi.org/10.36930/40291015 
(ЮНЕСКО-ЮНЕП, 1975 р.), Університетська хартія зі сталого розвитку (Женева, 1994 р.), Тбіліська декларація (ЮНЕСКО-ЮНЕП, 1977 р.), Салонікська декларація (ЮНЕСКО, 1997 р.), головні положення яких були консолідовані у "Порядку денному на XIX століття", прийнятому у 1992 р. в Ріо-де-Жанейро. Після проголошення Декади ООН "Освіта в інтересах сталого розвитку" на 2005-2014 рр. ОСР стала пріоритетним напрямом формування освітніх програм багатьох країн світу.

Іїі логічним продовженням є Регіональна Стратегія 3 Освіти для сталого розвитку, підготовлена і прийнята у 2005 р. Свропейською Економічною комісією (СЕК) ООНЮ, Програми дій "Освіта-2030" (ЮНЕСКО, 5 листопада 2015 р.), Рішення колегії МОН України "Про екологізацію вищої освіти України з метою підготовки фахівців для сталого розвитку" від 27 листопада 2015.

Аналіз міжнародних документів та наукових публікацій свідчить, що система ОСР загалом, як сама концепція сталого розвитку, складається з трьох рівнозначних підсистем - екологічної, соціальної та економічної. Первинною 3 цих підсистем є екологічна підсистема. Саме вона повинна забезпечити вивчення екологічних параметрів сталого розвитку, загальних природничих принципів і законів розвитку суспільства, а також причин і наслідків розвитку глобальних екологічних проблем взаємодії суспільства і природного життєвого довкілля. Завданням екологічної підсистеми в системі ОСР $€$ формування екологічного мислення здобувачів вищої освіти.

Проблеми ОСР досліджено в роботах Ю. Ю. Туниці, М. Г. Адамовського, О. В. Врублевської, В. М. Боголюбова, І. А. Дубовіча, Л. Д. Загвойської, І. П. Магазинщикової, І. М. Синякевича та інших науковців.

Ухвалою Колегії МОН України (Stalyi rozvytok, 2015) Науково-методичній раді МОН та Національному агентству із забезпечення якості вищої освіти було рекомендовано під час розроблення методології та методичних рекомендацій із підготовки стандартів вищої освіти включати екологічну компетентність фахівця до переліку ключових компетентностей.

Викладення основного матеріалу. Національна рамка кваліфікацій визначає компетентність чи компетентності як "здатність особи до виконання певного виду діяльності, що виражається через знання, розуміння, уміння, цінності, інші особисті якості" (Kvalifikatsiia, 2011).

В Законі України "Про вищу освіту" в дещо розширеному вигляді компетентність визначається як "динамічна комбінація знань, вмінь і практичних навичок, способів мислення, професійних, світоглядних і громадянських якостей, морально-етичних цінностей, яка визначає здатність особи успішно здійснювати професійну та подальшу навчальну діяльність і $є$ результатом навчання на певному рівні вищої освіти" (Osvita, 2011).

Отже, у загальноприйнятому й узаконеному визначенні терміну "Компетентність" можна умовно виділити когнітивну (знання, вміння, навички), психологічну (способи мислення), світоглядну, громадянську, морально-етично ціннісну, професійно-навчальну та результативно-рівневу складові. Що стосується когнітивної або фахової складової (знання, вміння, навички), то iii теоретичні та прикладні аспекти достатньо повно висвітлені в навчально-методичних джерелах у контексті діяльності загальноосвітньої та вищої освіти і сьогодні не викликають особливих дискусій.

Способи мислення є категорією, яка трапляється здебільшого у профорієнтаційних дослідженнях та у професіограмах і визначається як стала психологічна характеристика особистості. Зокрема вважаємо, що для економістів, менеджерів, керівників є властивим такий домінуючий спосіб мислення, як адаптування-координування для бухгалтерів, аудиторів, екологів - прикладення-регулювання (Professiogramma, 2019).

Цікавою $з$ погляду спроможності особи набувати тих чи інших компетентностей є теорія множинного інтелекту американського психолога Говарда Гарднера, який стверджує, що кожна людина володіє, принаймні, дев'ятьма індивідуально вираженими типами інтелекту. Тому, на думку цього вченого, високофаховими бухгалтерами, економістами, математиками, програмістами можуть стати особи, які мають домінуючий тип логікоматематичного інтелекту; менеджерами, маркетологами, психологами - особи $з$ розвинутим міжособистісним інтелектом; екологами - 3 натуралістичним інтелектом; дизайнерами, архітекторами, художниками - 3 візуально-просторовим інтелектом тощо (Gardner, 2007; Hordon, \& Dzhannet, 2005).

Окрім способів мислення, у філософії та психології поширеними є терміни "стилі мислення", "типи мислення", "види мислення", "професійне мислення". Зокрема "Філософський енциклопедичний словник", укладений Інститутом філософії ім. Г. С. Сковороди, визначає стиль мислення як "концептуальний лад використання методу, характеристика стандартних уявлень його занурення в конкретний матеріал, що визначається розкриттям у науці та культурі евристичних можливостей певних фундаментальних понять чи категорій" (Shynkaruk, 2002).

У психології прийнято розрізняти за змістом такі види мислення: наочно-дійове, наочно-образне та абстрактне мислення; за характером задач: практичне i теоретичне мислення; за ступенем новизни й оригінальності: репродуктивне (відтворювальне) і творче (продуктивне) мислення. За ступенем розгорнутого виконання завдань виділяють логічне, опосередковане мислення та інтуїтивне - миттєве, що характеризується мінімальною усвідомленістю, а також професійне мислення (Tunytsi, 2011). Отже, у визначенні компетентності доречніше було б вживати терміни "типи мислення" i "види мислення", одним із яких є "професійне мислення".

Як відомо, філософський зміст поняття "якість" вперше було розкрито в Арістотелівській логіці. Прабатько всіх філософів визначив якість як одну з 10 категорій, на які Арістотель поділив усі речі реальності. Як одна 3 основних категорій, якість - це побічна обставина, за допомогою якої річ $є$ якогось типу чи виду; побічна обставина, що вказує якою є річ (ії змістовні якості та форми) і як річ діє (іiі здатності та навички); побічна обставина, котра $\epsilon$ зовнішньою оцінювальною формою, відповідає на запитання: якого гатунку ця річ, наприклад: зелена, солодка, щаслива, хоробра тощо? (Shynkaruk, 2002).

3 цього погляду термін "світоглядні якості" нам видається не зовсім коректним. Світогляд - це самовизначення людини щодо їі місця у світі та взаємовідносин 3 ним. Світогляд властивий кожній людині, незалежно 
від того, чи є він раціонально усвідомлений. Виділяють три основні типи світогляду - життєвий (буденний), релігійний і філософський (Shynkaruk, 2002). Світоглядною філософською основою екологічних, економічних, еколого-економічних компетентностей здобувачів вищої освіти $\epsilon$ екоцентризм як світоглядно-етична парадигма сталого розвитку (Tunytsi, 2011). Отже, у визначенні компетентності, очевидно, маються на увазі не світоглядні якості, а світоглядні засади, орієнтири, переконання, принципи, а краще - "світогляд".

Зважаючи на філософське розуміння категорії "якість", громадянські якості - це зовнішня оцінювальна форма громадянськості, яка може бути як позитивною, так і негативною. Тому термін "громадянськість" у визначенні компетентності, на нашу думку, є доречнішим. Адже громадянськість - це усвідомлення кожним громадянином своїх прав та обов'язків щодо держави, суспільства (Busel, 2004).

Морально-етичні цінності у своїй сукупності утворюють етичну культуру особистості, яка є історично конкретною і соціально зумовленою мірою опанування людиною етичних максим і практичного втілення їх у різних сферах діяльності та поведінки (Shynkaruk, 2002). Руйнування сталої системи морально-етичних цінностей призводить до втрати морального здоров'я суспільства і є однією з основних причин екологічної та економічної криз. Підсумовуючи розгорнуте аналізування терміну "компетентність", можна спробувати дати визначення екологічної та економічної компетентностей.

Екологічна компетентність - динамічна комбінація екологічних знань, вмінь і практичних навичок, екоцентричних світоглядних засад, професійного (екологічного) мислення, фахових і громадянських якостей, морально-етичних цінностей, яка визначає здатність особи успішно здійснювати професійну та подальшу навчальну діяльність і $є$ результатом навчання за відповідною освітньо-професійною (освітньо-науковою) програмою на певному рівні вищої освіти.

Економічна компетентність - динамічна комбінація економічних знань, вмінь і практичних навичок, екоцентричних світоглядних засад, професійного (економічного) мислення, фахових і громадянських якостей, морально-етичних цінностей, яка визначає здатність особи успішно здійснювати професійну та подальшу навчальну діяльність і є результатом навчання за відповідною освітньо-професійною (освітньо-науковою) програмою на певному рівні вищої освіти.

Формування екологічної компетентності здобувачів вищої освіти досягається шляхом системного неперервного екологізування всього освітньо-виховного процесу. Глибинна сутність екологізування освіти "полягає насамперед в обов'язковому грунтовному вивченні студентами екологічних дисциплін та максимально можливому творчому і кваліфікованому наповненні змісту всіх інших навчальних дисциплін екологічними знаннями" (Tunytsia et al., 2015).

Грунтовне вивчення студентами екологічних дисциплін повинно передбачати включення до стандартів освіти освітньо-професійних програм і навчальних планів таких дисциплін, як: "Загальна екологія", "Техноекологія", "Аграрна екологія", "Лісова екологія", "Оцінювання антропогенного впливу на довкілля" тощо.
Потреба забезпечення творчого і кваліфікованого наповнення змісту інших нормативних та вибіркових "неекологічних" навчальних дисциплін екологічними знаннями передбачає фахове постійне і неперервне екологічне навчання насамперед тих, хто навчає, тобто всіх викладачів вищих начальних закладів. Воно повинно відбуватися шляхом екологізування підготовки і перепідготовки науково-педагогічних працівників, тобто набуття ними системних екологічних компетентностей. Ці компетентності також повинні оцінюватися уповноваженим компетентним органом і підтверджуватися документом встановленого взірця.

Системні екологічні та економічні еколого-економічні компетентності, які передбачають усвідомлене використання у навчальній, науковій, виробничій та повсякденній діяльності законів функціонування та взаємозв'язків природних і соціальних систем, є підгрунтям для формування еколого-економічних компетентностей і професійного еколого-економічного мислення здобувачів вищої освіти.

Отже, еколого-економічна компетентність формується як динамічна комбінація екологічних, економічних знань, вмінь і практичних навичок, екоцентричних світоглядних засад, еколого-економічного мислення, професійних і громадянських якостей, морально-етичних цінностей, яка визначає здатність особи успішно здійснювати професійну та подальшу навчальну діяльність і є результатом навчання за відповідною освітньопрофесійною (освітньо-науковою) програмою на певному рівні вищої освіти.

При цьому еколого-економічне мислення розглядають не тільки як складову еколого-економічної компетентності, а як основну мету екологізування освітньої діяльності. Фахове еколого-економічне мислення здобувачів вищої освіти сьогодні повинно формуватися паралельно з набуттям ними базових екологічних, економічних та еколого-економічних компетентностей.

Це може досягатися завдяки заміні предметної форми організації знань на проблемні форми іiі організації. Також необхідне зміщення акценту зі звиклого інформування студентів на самопошук ними навчальної інформації, самооволодіння нею та умінням iї застосовувати у процесі активної власної творчої діяльності. При цьому освітньо-виховний процес повинен створюватися на засадах фундаментальності, науковості, системності, цілісності та генералізації знань, на партнерських стосунках його суб'єктів.

Загалом набуття студентами інтегральних екологоекономічних компетентностей та формування екологоекономічного мислення здобувачів вищої освіти може здійснюватися за трьома напрямами:

• поглибленням екологічної підготовки фахівців економічних спеціальностей;

- поглибленням економічної підготовки фахівців природничого (екологічного) спрямування;

• поглибленням екологічної та економічної підготовки фахівців усіх інших спрямувань.

Набуття компетентності та оволодіння фаховим еколого-економічним мисленням - завдання не тільки навчального закладу, але і здобувача вищої освіти, адже вони насамперед набуваються самою особою, тобто ії усвідомленням необхідності певних компетентностей у майбутній роботі для виконання своїх професійних функцій і у процесі вирішення багатьох життєвих проблем. 


\section{Висновки:}

1. Формування еколого-економічного мислення фахівців для сталого розвитку повинно здійснюватися шляхом творчого застосування сучасних досягнень дидактики відповідно до специфіки підготовки фахівців різного професійного спрямування, а також з урахуванням інтелектуальних відмінностей студентів окремих спеціальностей та їх вродженої схильності до набуття ними певних компетентностей - природничих (екологічних), інженерно-технічних, економічних, соціально-гуманітарних, мистецьких тощо.

2. Набуття студентами інтегральних еколого-економічних компетентностей та формування еколого-економічного мислення здобувачів вищої освіти може здійснюватися шляхом екологізування підготовки фахівців економічних спеціальностей, економізуванням підготовки фахівців природничого (екологічного) спрямування, екологізуванням та економізуванням підготовки фахівців усіх інших спрямувань.

3. Кінцевою метою екологізування процесу підготовки фахівців для сталого розвитку є набуття ними системних еколого-економічних компетентностей та формування фахового еколого-економічного мислення, які грунтуються на усвідомленні здобувачами вищої освіти законів функціонування природних і соціальних систем та вмінні творчо застосовувати їх у професійній та повсякденній діяльності.

\section{References}

Agenda. (2015). Transforming our world: the 2030 Agenda for Sustainable Development. Retrieved from: https://sustainabledevelopment.un.org/post2015/transformingourworld

Busel, V. T. (Ed.). (2004). Velykyi tlumachnyi slovnyk suchasnoi ukrainskoi movy. Kyiv, Irpin: VTF "Perun ", 1440 p. [In Ukrainian].
Ekolohizatsiia. (2009). Dopovidna zapyska "Pro ekolohizatsiiu vyshchoi osvity Ukrainy z metoiu pidhotovky fakhivtsiv dlia staloho rozvytku". Retrieved from: http://nltu.edu.ua/index.php? option=com content\&view=article\&id=843:-q-q\&catid=13:2009-1210-10-49-15\&Itemid=244. [In Ukrainian].

Gardner, G. (2007). Frames of Mind. The Theory of Multiple Intelligence. Moscow: Viliams, 512 p. [In Russian].

Hordon, D., \& Dzhannet, V. (2005). Revoliutsiia v navchanni. (Oliinyk M. Trans). Lviv: Chronicle, 542 p. [In Ukrainian].

Kvalifikatsiia. (2011). Natsionalna ramka kvalifikatsii. Dodatok do postanovy Kabinetu Ministriv Ukrainy vid 23 lystopada 2011 r., \# 1341. Retrieved from: http://zakon3.rada.gov.ua/laws/show/13412011-p. [In Ukrainian].

Osvita. (2011). Zakon Ukrainy "Pro vyshchu osvitu". Retrieved from: http://zakon5.rada.gov.ua/laws/show/1556-18. [In Ukrainian].

Professiogramma. (2019). Instruktciia po chteniiu professiogramm. Retrieved from: http://narfu.ru/agtu/www.agtu.ru/2e9f1379a98d86f023562aec421aaa46professiogramma.html. [In Russian].

Shynkaruk, V. I. (Ed.) (2002). Filosofskyi entsyklopedychnyi slovnyk. NAN Ukrainy, In-t filosofii im. H. S. Skovorody. Kyiv: Abrys, 742 p. [In Ukrainian].

Stalyi rozvytok. (2015). Rishennia Kolehii MON Ukrainy vid 27.11.2015 p. "Pro ekolohizatsiiu vyshchoi osvity z metoiu pidhotovky fakhivtsiv dlia staloho rozvytku". Retrieved from: http://mon.gov.ua/content/Новини/2015/12/30/10-5-4.zip. [In Ukrainian].

Tunytsi, Yu. Yu. (Ed.). (2011). Ekolohichna Konstytutsiia Zemli. Metodolohichni zasady. Lviv: RVV NLTU Ukrainy, 440 p. [In Ukrainian].

Tunytsia, Yu. (2010). Vchytysia zhyty v harmonii z pryrodoiu. Education of Ukraine, 85, 6-8. [In Ukrainian].

Tunytsia, Yu. Yu., Adamovskyi, M. H., Borys, M. M., Kraievskyi, S. N., \& Mahazynshchykova, I. P. (2015). Ekolohizatsiia osvity yak kliuchovyi faktor pidhotovky fakhivtsiv dlia staloho rozvytku. Scientific Bulletin of UNFU, 25(10), 348-356. https://doi.org/10.15421/40251053

P. K. Dynka

Ukrainian National Forestry University, Lviv, Ukraine

\section{ENVIROMENRAL AND ECONOMIC COMPETENCES AS A PREREQUISITE FOR EVIRONMENTAL AND ECONOMIC THINKING DEVELOPMENT BY STUDENTS OF HIGHER EDUCATION INSTITUTIONS}

The main component of education for sustainable development is the greening of educational activities, which ensures the overall greening of the public consciousness through the continuous development of high-quality environmental awareness, forming of high level social and moral responsibility for the state of natural environment, promotion of life-style consistent with the sustainable development principles. The means and purpose of the greening of process of training specialists for sustainable development are their acquisition with system of environmental and economic competencies and environmental and economic thinking forming, which is based on the awareness of the laws of natural and social systems functioning and the ability to apply them creatively in professional and everyday activities. Environmental and economic thinking is considered to be one of the types of professional thinking that determines the person's ability to perform successfully professional and further educational activities and there is the result of training on the corresponding educationally-professional (educationally-scientific) program. The environmental and economic thinking of specialists for sustainable development is formed through the creative application of modern achievements of didactics in accordance with the specifics of training specialists of various professional fields, as well as considering the intellectual differences between lecturers and students of certain specialities and their innate tendency to predominantly acquire certain competencies such as natural (environmental), technical (engineering), economic, social-humanitarian, artistic, etc. The main directions of environmental and economic thinking formation for students of higher education institutions are deepening of environmental training of students of economic specialities, natural (environmental) direction, and of all other fields of study.

Keywords: education for sustainable development; environmental competence; economic competence; environmental and economic competence; environmental and economic thinking. 